\title{
Synthesis parameter dependence of the electrochemical performance of solvothermally synthesized $\mathrm{Li}_{4} \mathrm{Ti}_{5} \mathrm{O}_{12}$
}

\author{
Qian Yang $\cdot$ Hailei Zhao $\cdot$ Jie Wang $\cdot$ \\ Jing Wang $\cdot$ Chunmei Wang $\cdot$ Xinmei Hou
}

Received: 6 September 2013/Accepted: 3 February 2014/Published online: 22 February 2014

(C) The Author(s) 2014. This article is published with open access at Springerlink.com

\begin{abstract}
Pure $\mathrm{Li}_{4} \mathrm{Ti}_{5} \mathrm{O}_{12}$ with high crystallinity was successfully synthesized by a solvothermal process. The effects of initial $\mathrm{Li} / \mathrm{Ti}$ ratio and post-heating temperature on the phase evolution, particle morphology and electrochemical properties were systematically investigated. Excess lithium, compared to the theoretical value in $\mathrm{Li}_{4} \mathrm{Ti}_{5} \mathrm{O}_{12}$, was required to get pure $\mathrm{Li}_{4} \mathrm{Ti}_{5} \mathrm{O}_{12}$ due to the condensation reaction. Low $\mathrm{Li} / \mathrm{Ti}$ ratio led to the appearance of secondary phase rutile $\mathrm{TiO}_{2}$, while high heattreatment temperature easily resulted in particle agglomeration of $\mathrm{Li}_{4} \mathrm{Ti}_{5} \mathrm{O}_{12}$ powder. The existence of rutile $\mathrm{TiO}_{2}$ decreased the specific capacity, and the particle agglomerate had a strong negative effect on the rate capability of electrode. The sample synthesized at the optimized condition exhibited a stable specific capacity of $150 \mathrm{mAh} / \mathrm{g}$ and a good rate performance.
\end{abstract}

Keywords $\mathrm{Li}_{4} \mathrm{Ti}_{5} \mathrm{O}_{12} \cdot$ Solvothermal synthesis $\cdot$ Heat treatment $\cdot$ Electrochemical performance

Q. Yang $\cdot$ H. Zhao $(\bowtie) \cdot$ J. Wang $\cdot$ J. Wang $\cdot$ C. Wang

School of Materials Science and Engineering, University of Science and Technology Beijing, Beijing 100083, China e-mail: hlzhao@ustb.edu.cn

H. Zhao

Beijing Key Lab of Advanced Energy Materials, Beijing 100083, China

X. Hou

School of Metallurgical and Ecological Engineering, University of Science and Technology Beijing, Beijing 100083, China

\section{Introduction}

Lithium-ion batteries have attracted much attention as important energy supply in portable electronic devices, hybrid electrical vehicles and electrical vehicles because of their high power and energy density [1-3]. At present, new electrode materials exhibiting excellent rate capability and high safety performance are urgently demanded to meet the requirement of electrical vehicles. The spinel lithium titanate $\mathrm{Li}_{4} \mathrm{Ti}_{5} \mathrm{O}_{12}$ is being considered as an ideal anode material in lithium-ion batteries due to its unique characteristics, including very flat charge/discharge voltage plateaus and a small structural change during charge/discharge processes. The zero-strain insertion characteristic provides material with an excellent cycling performance [4, 5], while that of the flat operating voltage at $1.55 \mathrm{~V}$ (versus $\mathrm{Li}^{+} / \mathrm{Li}$ ) can avoid the deposition of dendritic metallic lithium, therefore a high operational safety can be expected $[6,7]$. Despite the high Li deintercalation/intercalation potential, it can, in principle, be coupled with high-voltage cathodes such as $\mathrm{LiNi}_{0.4} \mathrm{Mn}_{1.6} \mathrm{O}_{4}$ to provide a cell with an operating voltage of approximately $3 \mathrm{~V}$ [8].

However, $\mathrm{Li}_{4} \mathrm{Ti}_{5} \mathrm{O}_{12}$ is an insulator, its rate capability is greatly limited by its inherently low lithium-ion diffusivity and electronic conductivity. Typical approaches to resolve this problem include employing nanoparticles to reduce the diffusion length of lithium ions, and increase the contact area between the electrode and the electrolyte [9-11], doping $\mathrm{Li}_{4} \mathrm{Ti}_{5} \mathrm{O}_{12}$ with aliovalent cation $\left(\mathrm{Al}^{3+}, \mathrm{Ga}^{3+}\right.$, $\left.\mathrm{Co}^{3+}, \mathrm{Mg}^{2+}, \mathrm{Ta}^{5+}\right)[12-14]$ in $\mathrm{Li}$ and $\mathrm{Ti}$ sites to produce mixed valence of $\mathrm{Ti}^{3+} / \mathrm{Ti}^{4+}$, and thus increase the electronic conductivity, and incorporating directly the conductive second phase (carbon, Ag and so on) [7, 15, 16].

Actually, the particle size and the crystalline ordering degree have strong impacts on the electrochemical 
properties of electrode. Small-sized active material can not only reduce the lithium-ion diffusion distance, but also increases the contact area with conductive reagent and electrolyte solution, thus can decrease the local current density and mitigate the electrode polarization. The high crystallinity is believed to be beneficial to the good cycling stability of electrode [9]. Compared to the doped materials, the pure material is easier to be synthesized and handled in practical operations. Many methods, including conventional solid-state reaction [12-14], sol-gel method [6, 17, 18], solvothermal technique [19-22], combustion synthesis [23], rheological phase reaction [11] and other synthesis routes, have been exploited to prepare $\mathrm{Li}_{4} \mathrm{Ti}_{5} \mathrm{O}_{12}$ materials. Among them, solvothermal technique with simple and flexible controls has spurred considerable interests. Although $\mathrm{Li}_{4} \mathrm{Ti}_{5} \mathrm{O}_{12}$ powders prepared by solvothermal method have been investigated extensively [19-22], the work concerning the effect of the synthesis parameters on the electrochemical properties is very limited. Considering that the practical composition of the synthesized material via solvothermal route is usually different from the nominal composition, in this work, the effect of initial $\mathrm{Li} / \mathrm{Ti}$ ratio in starting solution on the phase purity and the electrochemical properties was investigated. The influence of the post-heat-treatment temperature on the electrochemical performance of $\mathrm{Li}_{4} \mathrm{Ti}_{5} \mathrm{O}_{12}$ electrode was also addressed. The synthesized $\mathrm{Li}_{4} \mathrm{Ti}_{5} \mathrm{O}_{12}$ exhibited excellent rate capability and cycling performance, showing the solvothermal synthesis is a promising method to obtain high-performance $\mathrm{Li}_{4} \mathrm{Ti}_{5} \mathrm{O}_{12}$ anode material.

\section{Experimental}

Materials synthesis

The spherical precursors of $\mathrm{Li}_{4} \mathrm{Ti}_{5} \mathrm{O}_{12}$ powders were synthesized by solvothermal method using lithium acetate (LiAc, AR $\geq 99.0 \%$, Beijing Yili Fine Chemicals Co., Ltd.) and tetrabutyl titanate $\left[\mathrm{Ti}\left(\mathrm{O}\left(\mathrm{CH}_{2}\right)_{3} \mathrm{CH}_{3}\right)_{4}\right.$, denoted as $\mathrm{Ti}(\mathrm{OR})_{4}, \mathrm{AR} \geq 99.0 \%$, Beijing Jinlong Chemical Reagent Co., Ltd.) as $\mathrm{Li}$ and $\mathrm{Ti}$ cation sources, respectively. The molar ratios of the mixtures were fixed at different proportions $(\mathrm{Li} / \mathrm{Ti}$ ratio $=0.8-1.4)$. $\mathrm{Ti}(\mathrm{OR})_{4}$ was dissolved in ethanol under magnetic stirring, and then LiAc was added into the mixtures with further stirring to obtain a homogeneous dispersion system. The concentration of $\mathrm{Ti}(\mathrm{OR})_{4}$ in ethanol was $1.4 \times 10^{-4} \mathrm{~mol} / \mathrm{ml}$. The transparent solution was then transferred into a $100 \mathrm{ml}$ teflon-lined stainless steel autoclave and kept at $180{ }^{\circ} \mathrm{C}$ for $24 \mathrm{~h}$. After cooling down to room temperature, a milky white precursor was prepared. The produced powder was washed and filtered with ethanol to eliminate the unreacted reagents and the partial organic compounds. The precipitate was dried at $80{ }^{\circ} \mathrm{C}$ in air for $3 \mathrm{~h}$. To obtain well-crystallized $\mathrm{Li}_{4} \mathrm{Ti}_{5} \mathrm{O}_{12}$, the precursor was calcined at $800{ }^{\circ} \mathrm{C}$ for $2 \mathrm{~h}$ in air with a heating rate of $5^{\circ} \mathrm{C} / \mathrm{min}$. At last, the effect of heat-treatment temperature on the particle morphology and electrochemical properties was investigated. The precursor with the optimal $\mathrm{Li} / \mathrm{Ti}$ ratio based on the above results was subjected to calcination at temperatures of 400,600, and $800{ }^{\circ} \mathrm{C}$, respectively.

\section{Characterization}

Phase purity and crystallinity of the synthesized samples were identified by means of powder X-ray diffraction (XRD) performed on a Rigaku D/MAX-A diffractometer with $\mathrm{Cu} \mathrm{K} \alpha$ radiation source $(\lambda=1.54056 \AA)$ in the range of $10^{\circ} \leq 2 \theta \leq 90^{\circ}$, while the morphology and size distribution of precursors and post-treated powders were observed on a LEO-1450 scanning electron microscope (SEM). The actual molar ratio of Li/Ti in the precursor was determined by inductively coupled plasma atomic emission spectrometer (ICP-AES) (IRIS Intrepid II XSP). The thermal behavior of the precursor powders was examined by a thermogravimetry-differential thermal analysis (TGDTA) instrument (Netzsch STA $449 \mathrm{C}$ ) with a heating rate of $10{ }^{\circ} \mathrm{C} / \mathrm{min}$ from room temperature to $900{ }^{\circ} \mathrm{C}$ under air.

\section{Electrochemical measurement}

Half-cells were used to evaluate the electrochemical performance. Celgard 2400 microporous membrane was used as separator, a lithium foil as negative electrode, and $1 \mathrm{M}$ $\mathrm{LiPF}_{6}$ dissolved in a mixture of ethyl methyl carbonate (EMC), dimethyl carbonate (DMC) and ethylene carbonate (EC) with a volume ratio of 1:1:1 as the electrolyte. The working electrode was made from the mixture of active material $\mathrm{Li}_{4} \mathrm{Ti}_{5} \mathrm{O}_{12}$, acetylene black $(\mathrm{AB})$ and polyvinylidene fluoride $(\mathrm{PVdF})$ in a weight ratio of 85:10:5. The slurry of the mixture was uniformly pasted on aluminum foil, dried and cut into disks. Then the working electrode was dried under vacuum at $120{ }^{\circ} \mathrm{C}$ for $24 \mathrm{~h}$ before electrochemical evaluation. Cell assembly was carried out in a glove box filled with high-purity argon where the oxygen and water vapor contents were each $<1 \mathrm{ppm}$.

The galvanostatic charging-discharging test was employed to evaluate the cycle stability and electrochemical capacity of the samples by a computer-controlled Land CT 2001A battery test system. The cell was cycled at different current densities, and the cut-off voltage for charging and discharging processes was $1.0-2.5 \mathrm{~V}$, respectively. The specific capacity was calculated based on the whole weight of the synthesized samples, including $\mathrm{Li}_{4} \mathrm{Ti}_{5} \mathrm{O}_{12}$ and possible impurity $\mathrm{TiO}_{2}$. AC electrochemical 
impedance spectroscopy was measured by a Solartron $1260 / 1287$ (UK) impedance analyzer in the frequency range from $1 \mathrm{MHz}$ to $0.01 \mathrm{~Hz}$ at the state of fully lithiated. Experiments were carried out at room temperature.

\section{Results and discussion}

\section{Effect of Li/Ti molar ratio}

Due to the complicated coordination process of tetrabutyl titanate $\left[\mathrm{Ti}(\mathrm{OR})_{4}\right]$ with $\mathrm{LiAc}$ in the solvothermal condition, the chemical composition of the resultant is usually different from the nominal composition. To prepare highpurity $\mathrm{Li}_{4} \mathrm{Ti}_{5} \mathrm{O}_{12}$, it is essential to control the starting molar ratio of $\mathrm{Li} / \mathrm{Ti}$ in the reaction mixtures. Different solutions with $\mathrm{Li} / \mathrm{Ti}$ ratio $=0.8,1.0,1.2$ and 1.4 were solvothermally treated in an autoclave, and the precipitates after heat treatment were subjected to the phase identification by XRD. The results are shown in Fig. 1. The samples with $\mathrm{Li} / \mathrm{Ti}$ molar ratios of $0.8,1.0,1.2,1.4$ are named as LTO0.8, LTO1.0, LTO1.2 and LTO1.4, respectively. For all samples, diffraction peaks indexed on the cubic spinel phase $\mathrm{Li}_{4} \mathrm{Ti}_{5} \mathrm{O}_{12}$ with $\mathrm{Fd} \overline{3} \mathrm{~m}$ space group (JCPDS No. 49-0207) are observed. However, some additional diffraction peaks corresponding to rutile $\mathrm{TiO}_{2}$ with $\mathrm{P} 42 / \mathrm{mnm}$ space group (JCPDS No. 21-1276) are also detected at the same time except for sample LTO1.4. Although the theoretical $\mathrm{Li} / \mathrm{Ti}$ ratio of $\mathrm{Li}_{4} \mathrm{Ti}_{5} \mathrm{O}_{12}$ is 0.8 , sample $\mathrm{LTO} 0.8$ shows strong $\mathrm{TiO}_{2}$ peaks, demonstrating that a significant amount of lithium remained in the solution. With increasing $\mathrm{Li} / \mathrm{Ti}$ ratio, the relative peak intensity of $\mathrm{Li}_{4} \mathrm{Ti}_{5} \mathrm{O}_{12}$ increases gradually, while that of $\mathrm{TiO}_{2}$ decreases

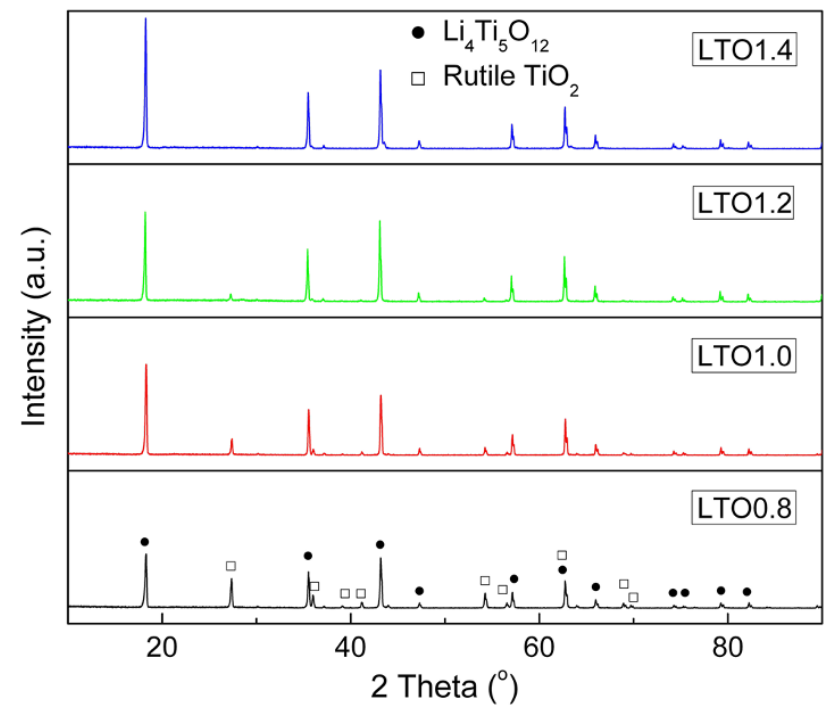

Fig. 1 XRD patterns of $\mathrm{Li}_{4} \mathrm{Ti}_{5} \mathrm{O}_{12}$ samples after heat treated at $800{ }^{\circ} \mathrm{C}$ in air remarkably and finally tends to disappear. When the molar ratio of $\mathrm{Li} / \mathrm{Ti}$ reaches 1.4 , the single-phase spinel type $\mathrm{Li}_{4} \mathrm{Ti}_{5} \mathrm{O}_{12}$ without any impurity is obtained.

Compared to the theoretical ratio, the excess lithium required to obtain pure single-phase $\mathrm{Li}_{4} \mathrm{Ti}_{5} \mathrm{O}_{12}$ in the solvothermal synthesis route is related to the reaction mechanism of $\mathrm{Ti}(\mathrm{OR})_{4}$ and LiAc. Under solvothermal condition, part of tetrabutyl titanate $\mathrm{Ti}(\mathrm{OR})_{4}$ may first resolve in ethanol and take alcoholysis reaction to form $\mathrm{Ti}(\mathrm{OR})_{4-x}(\mathrm{OH})_{x}$, as expressed by reaction (1). The $\mathrm{Ti}(\mathrm{OR})_{4}-{ }_{x}(\mathrm{OH})_{x}$ monomers then condense with LiAc to produce $\mathrm{Ti}(\mathrm{OR})_{4-x}(\mathrm{OH})_{x-y}(\mathrm{OLi})_{y}$ via reaction (2). Different condensation reactions occur among the clusters of $\mathrm{Ti}(\mathrm{OR})_{4-x}(\mathrm{OH})_{x-y}(\mathrm{OLi})_{y}$. The condensation may occur between $\mathrm{Ti}-(\mathrm{OH})$ groups, producing $\mathrm{H}_{2} \mathrm{O}$ as by-product, while the reaction may also occur between $\mathrm{Ti}-\mathrm{OH}$ and $\mathrm{Ti}-$ OLi producing $\mathrm{LiOH}$, corresponding to reaction (3) and (4), respectively. The product of the solvothermal reaction was composed of mainly $\mathrm{Li}-\mathrm{Ti}-\mathrm{O}$ amorphous material with some remained organic radicals that already show the basic lattice structure of $\mathrm{Li}_{4} \mathrm{Ti}_{5} \mathrm{O}_{12}$, as shown in Fig. 6 (sample LTO), and small amount of $\mathrm{LiOH}$ as by-product. Therefore, part of the lithium remains in the solution. If Li source LiAc is not excess in the starting materials than the theoretically required amount, then the attached lithium in the solid particles after condensation reactions (3) and (4) will be inadequate to form $\mathrm{Li}_{4} \mathrm{Ti}_{5} \mathrm{O}_{12}$, leading to the generation of trace of $\mathrm{TiO}_{2}$ after heat treatment, as evidenced in Fig. 1.

$\mathrm{Ti}(\mathrm{OR})_{4}+x \mathrm{C}_{2} \mathrm{H}_{5} \mathrm{OH} \rightarrow \mathrm{Ti}(\mathrm{OR})_{4-x}(\mathrm{OH})_{x}+x \mathrm{C}_{2} \mathrm{H}_{5} \mathrm{OR}$

$$
(0<x<4)
$$

$\mathrm{Ti}(\mathrm{OR})_{4-x}(\mathrm{OH})_{x}+y \mathrm{CH}_{3} \mathrm{COOLi}$

$$
\begin{aligned}
& \rightarrow \mathrm{Ti}(\mathrm{OR})_{4-x}(\mathrm{OH})_{x-y}(\mathrm{OLi})_{y}+y \mathrm{CH}_{3} \mathrm{COOH} \\
& (0<y<x)
\end{aligned}
$$

$2 \mathrm{Ti}(\mathrm{OR})_{4-x}(\mathrm{OH})_{x-y}(\mathrm{OLi})_{y}$

$$
\rightarrow(\mathrm{OLi})_{y}(\mathrm{OH})_{x-y-1}(\mathrm{RO})_{4-x} \mathrm{Ti}-\mathrm{O}-\mathrm{Ti}(\mathrm{OR})_{4-x}
$$$$
\times(\mathrm{OH})_{x-y-1}(\mathrm{OLi})_{y}+\mathrm{H}_{2} \mathrm{O}
$$

$2 \mathrm{Ti}(\mathrm{OR})_{4-x}(\mathrm{OH})_{x-y}(\mathrm{OLi})_{y}$

$$
\rightarrow(\mathrm{OLi})_{y-1}(\mathrm{OH})_{x-y}(\mathrm{RO})_{4-x} \mathrm{Ti}-\mathrm{O}-\mathrm{Ti}(\mathrm{OR})_{4-x}
$$$$
\times(\mathrm{OH})_{x-y-1}(\mathrm{OLi})_{y}+\mathrm{LiOH}
$$

Analyzed by means of ICP-AES, the actual Li/Ti molar ratio in the precursor of sample LTO1.4 is 1.0 , indicating that some lithium remained in solution, which is in good agreement with reaction (4). Considering that the $\mathrm{Li} / \mathrm{Ti}$ is 0.8 in $\mathrm{Li}_{4} \mathrm{Ti}_{5} \mathrm{O}_{12}$, the high $\mathrm{Li} / \mathrm{Ti}(1.0)$ in the precursor of LTO1.4 implies that some lithium is lost during calcination $[17,24,25]$.

To investigate the thermal decomposition behavior of the precursor, TG-DTA examination was performed on the 


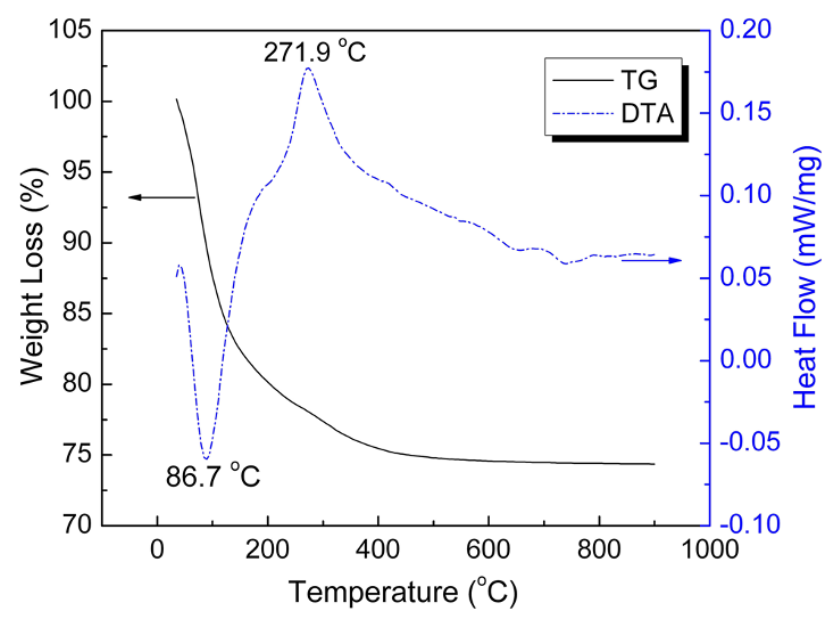

Fig. 2 TG-DTA curves of precursor with initial $\mathrm{Li} / \mathrm{Ti}=1.4$

precursor of sample LTO1.4. The result is shown in Fig. 2. In the TG curve, the total mass loss obtained in the temperature range from room temperature to $900{ }^{\circ} \mathrm{C}$ is approximately $25.64 \%$. The first step of mass loss about $19.06 \%$ occurred between room temperature and $180{ }^{\circ} \mathrm{C}$, corresponding to the endothermic peak at $86.7^{\circ} \mathrm{C}$ in the DTA curve, is due to the removal of adsorbed ethanol and water molecules. The second step of mass loss occurred in $180-600{ }^{\circ} \mathrm{C}$, associating with the exothermic peak at $271.9^{\circ} \mathrm{C}$, is attributed to the loss of the organics and the formation of $\mathrm{Li}_{4} \mathrm{Ti}_{5} \mathrm{O}_{12}$ phase. When the temperature is above $600{ }^{\circ} \mathrm{C}$, no major weight loss was examined, indicating that the decomposition of organic groups was completed.
The particle morphologies of $\mathrm{Li}_{4} \mathrm{Ti}_{5} \mathrm{O}_{12}$ precursors with different molar ratios of $\mathrm{Li} / \mathrm{Ti}$ are shown in Fig. 3. The samples are all composed of well-dispersed spherical particles with some small particles adhering to their surface. With increasing $\mathrm{Li} / \mathrm{Ti}$ ratio, the number of small particles decreases remarkably, the average particle size reduces from 3 to $2 \mu \mathrm{m}$ and the particle distribution tends to be more uniform.

After heat treatment at $800{ }^{\circ} \mathrm{C}$ in air, the powders exhibit even smaller particle size of about $1-1.5 \mu \mathrm{m}$ and smoother particle surface, as presented in Fig. 4. This is considered to be mainly resulted from the decomposition of organic groups on the particle surface of $\mathrm{Li}_{4} \mathrm{Ti}_{5} \mathrm{O}_{12}$ precursor.

With $\mathrm{Li}_{4} \mathrm{Ti}_{5} \mathrm{O}_{12} / \mathrm{Li}$ half-cell, the cycling performances of samples LTO0.8, LTO1.0, LTO1.2 and LTO1.4 at $0.2 \mathrm{C}$ were examined, and the results are shown in Fig. 5a. All the synthesized active materials of LTO0.8, LTO1.0, LTO1.2 and LTO1.4 display a stable cycling performance. The specific capacity of these samples increases with increasing $\mathrm{Li} / \mathrm{Ti}$ ratio, and sample LTO1.4 exhibits the highest specific capacity among these samples. The existence of rutile $\mathrm{TiO}_{2}$ is apparently detrimental to lithium storage capacity of the samples. This is in good agreement with the literature results that only small amounts of lithium ions can be intercalated in rutile $\mathrm{TiO}_{2}$ at room temperature $[26,27]$.

The initial discharge-charge potential curves of samples LTO0.8, LTO1.0, LTO1.2 and LTO1.4 are shown in Fig. 5 b. All the samples exhibit only one typical discharge/charge potential plateau of $\mathrm{Li}_{4} \mathrm{Ti}_{5} \mathrm{O}_{12}$ representing a two-phase reaction between $\mathrm{Li}_{4} \mathrm{Ti}_{5} \mathrm{O}_{12}$ and $\mathrm{Li}_{7} \mathrm{Ti}_{5} \mathrm{O}_{12}$ [28], no plateau corresponds to the lithiation/delithiation process of rutile $\mathrm{TiO}_{2}[29]$.
Fig. 3 SEM images of $\mathrm{Li}_{4} \mathrm{Ti}_{5} \mathrm{O}_{12}$ precursors obtained by solvothermal reaction with a $\mathrm{Li} / \mathrm{Ti}=0.8, \mathbf{b ~ L i} / \mathrm{Ti}=1.0$, c $\mathrm{Li} / \mathrm{Ti}=1.2, \mathbf{d ~ L i} / \mathrm{Ti}=1.4$
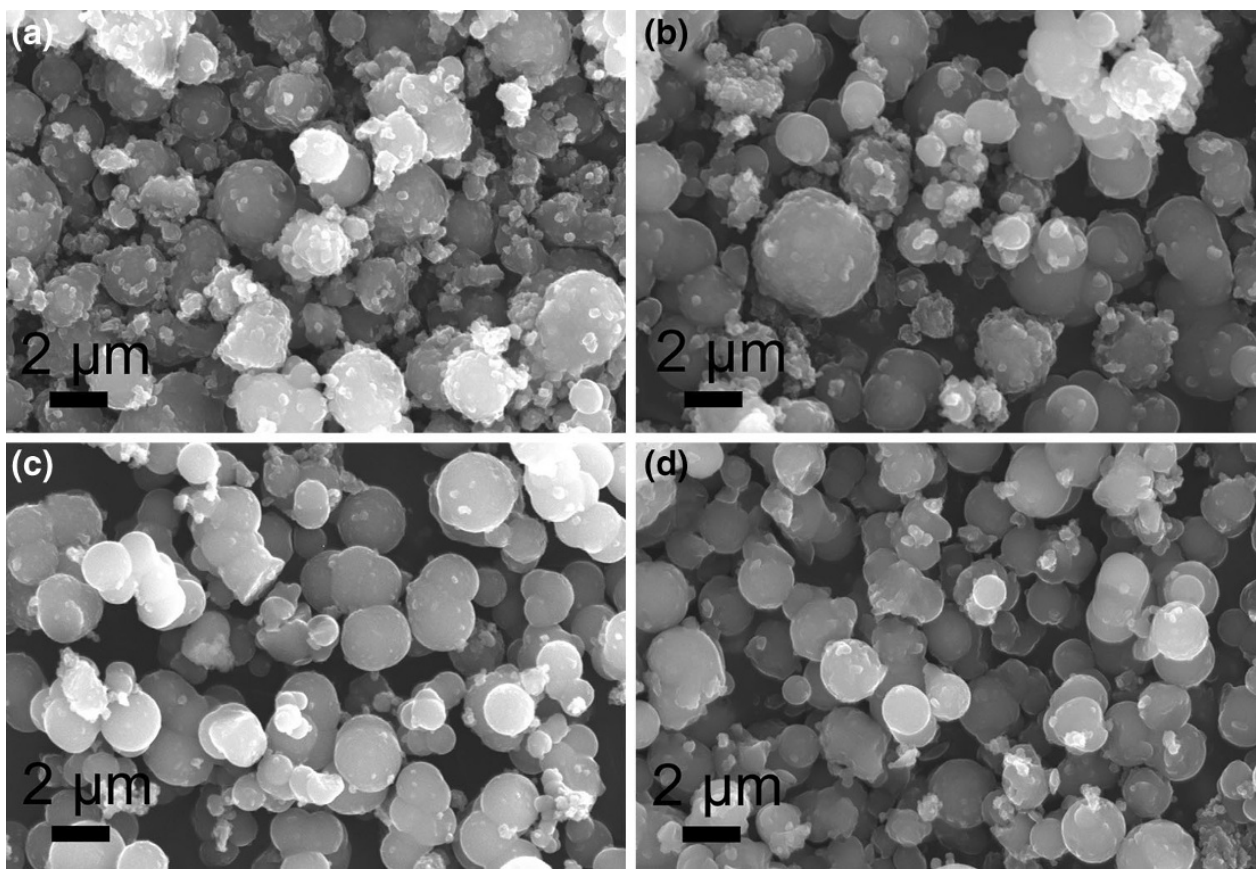
Fig. 4 SEM images of $\mathrm{Li}_{4} \mathrm{Ti}_{5} \mathrm{O}_{12}$ samples after heat treated at $800{ }^{\circ} \mathrm{C}$ in air a LTO0.8, b LTO1.0, c LTO1.2, d LTO1.4
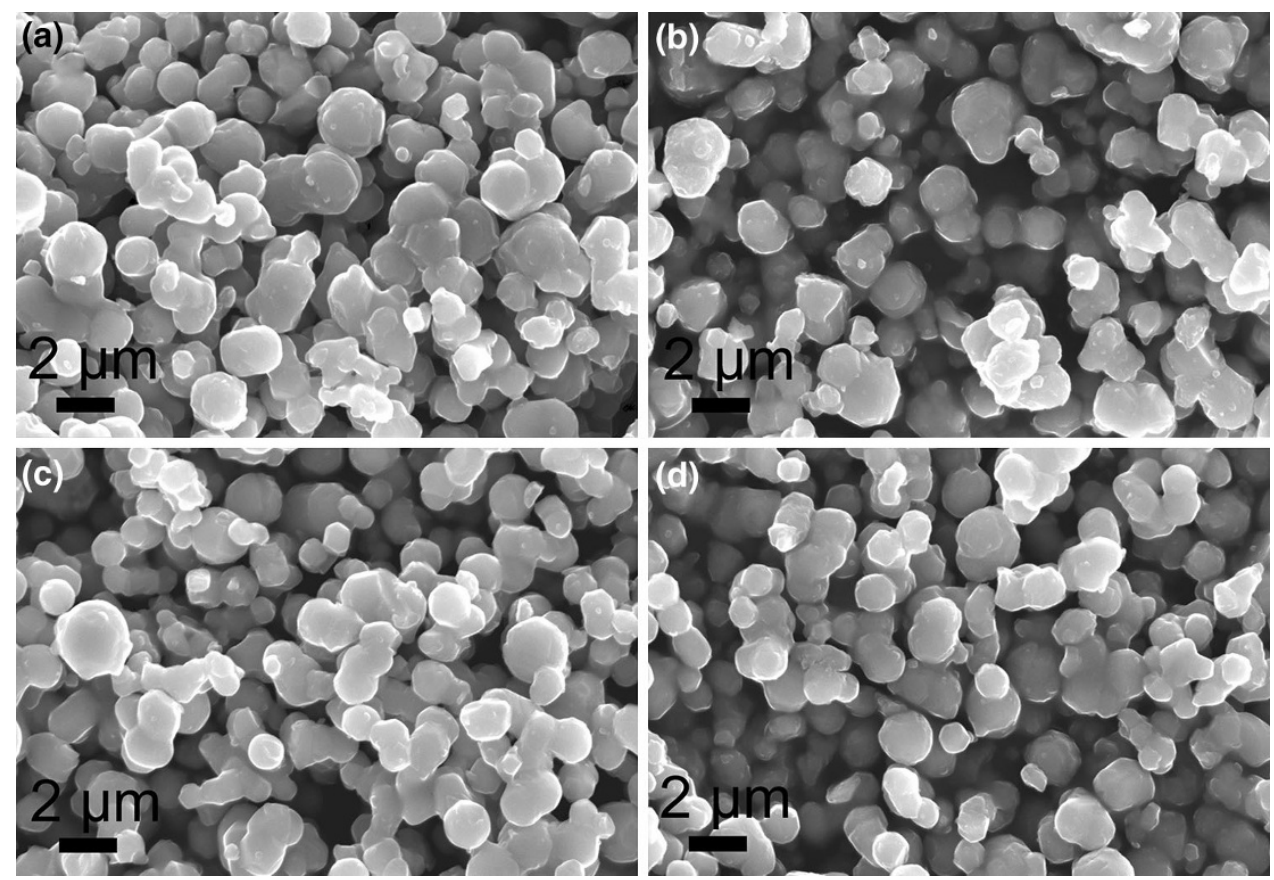
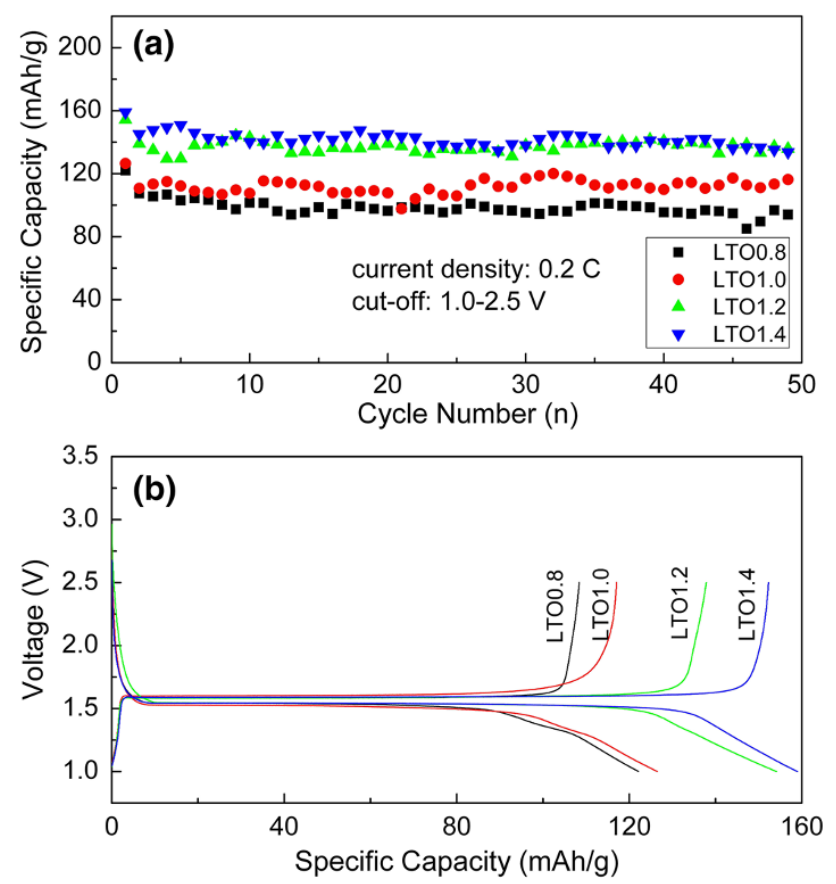

Fig. 5 a Discharge specific capacity of $\mathrm{Li}_{4} \mathrm{Ti}_{5} \mathrm{O}_{12}$ prepared from starting materials with different $\mathrm{Li} / \mathrm{Ti}$ ratios; b initial dischargecharge curves of the samples LTO0.8, LTO1.0, LTO1.2 and LTO1.4

The results indicate that the impurity rutile $\mathrm{TiO}_{2}$ in the samples does not have electrochemical activity in this condition.

\section{Effect of heat-treatment temperature}

Considering that the electrochemical performances of $\mathrm{Li}_{4} \mathrm{Ti}_{5} \mathrm{O}_{12}$ are closely related with its crystallinity, a further heat-treatment investigation was conducted. Precursor of sample LTO1.4, showing pure phase and high specific capacity after $800{ }^{\circ} \mathrm{C}$-treatment, was selected to subject the heat-treatment test to clarify the effect of treating temperature on the structure and electrochemical performance of synthesized $\mathrm{Li}_{4} \mathrm{Ti}_{5} \mathrm{O}_{12}$. The precursor and the samples heat treated at 400,600 and $800{ }^{\circ} \mathrm{C}$ are denoted as LTO, LTO4, LTO6 and LTO8, accordingly. Figure 6 shows the XRD patterns of these samples. They are all identified with a pure cubic phase $\mathrm{Li}_{4} \mathrm{Ti}_{5} \mathrm{O}_{12}$. The precursor features amorphous structure. The appearance of messy background and the broad peaks with weak intensities indicate the poor crystallinity of the formed precursor. The peak intensities of the spinel phase significantly enhance when the heattreatment temperature increases, exhibiting the improvement of crystallinity. When the heat-treating temperature is up to $600{ }^{\circ} \mathrm{C}$, good crystallinity and pure spinel phase $\mathrm{Li}_{4} \mathrm{Ti}_{5} \mathrm{O}_{12}$ have been identified from the XRD data. The lattice parameters calculated according to the XRD data are 8.3395 (3), 8.3661 (9), 8.3695 (9) $\AA$ for LTO4, LTO6 and LTO8, respectively, which are in good agreement with previous reported values $[6,30,31]$. The average crystallite sizes calculated from the full width at half maximum (FWHM) of peak (111) are 11.47, 44.70 and $50.04 \mathrm{~nm}$ for LTO4, LTO6 and LTO8, respectively. The crystallite size increases with the increase of heat-treatment temperature. The results demonstrate that pure $\mathrm{Li}_{4} \mathrm{Ti}_{5} \mathrm{O}_{12}$ powders with high crystallinity, small crystallite size can be successfully synthesized by solvothermal method. Additionally, the synthesized $\mathrm{Li}_{4} \mathrm{Ti}_{5} \mathrm{O}_{12}$ powders display high dispersity and good sphericity without particle agglomeration, which are

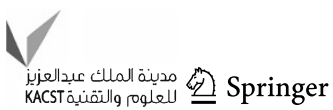




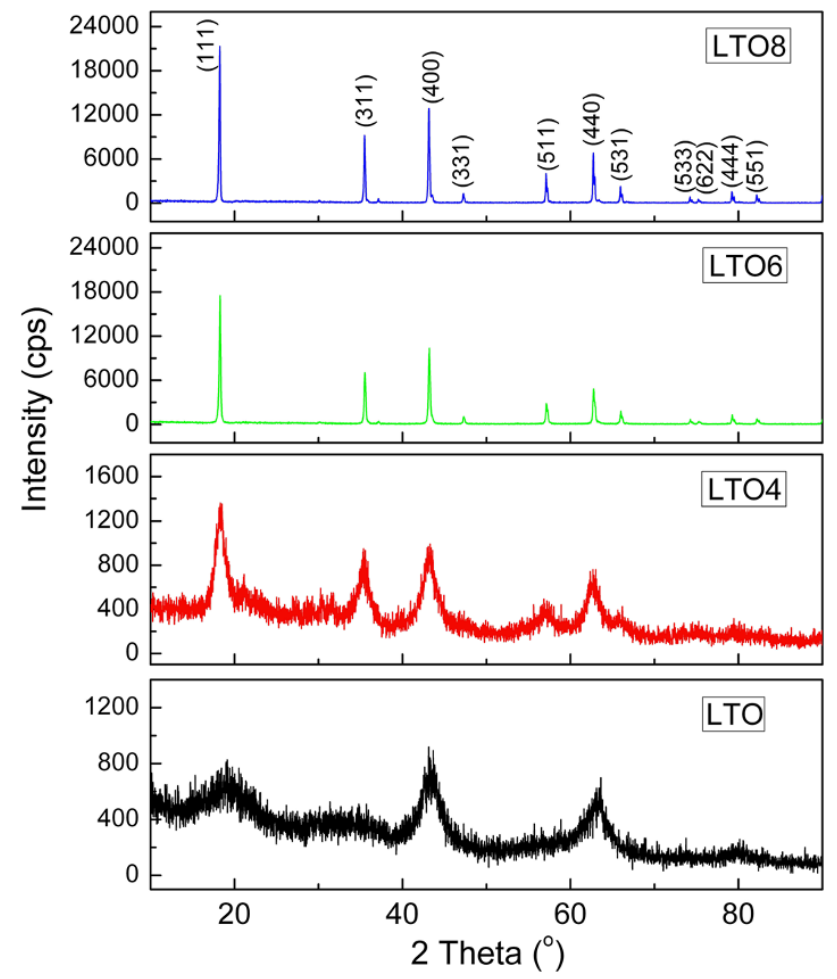

Fig. 6 XRD patterns of the precursor and the final powders calcined at different temperatures

beneficial for both of electrochemical performance and practical electrode preparation. In most previous studies, spinel $\mathrm{Li}_{4} \mathrm{Ti}_{5} \mathrm{O}_{12}$ was synthesized by solid-state reaction at

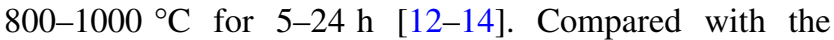
conventional solid-state technique, the calcination temperature of the solvothermally synthesized products was greatly decreased and the dwelling time was significantly shortened.

The morphologies of the $\mathrm{Li}_{4} \mathrm{Ti}_{5} \mathrm{O}_{12}$ powders after heat treatment are shown in Fig. 7. With increasing temperature, the particle size decreases slightly and the particle surface becomes much smoother. However, the $800{ }^{\circ} \mathrm{C}$ treated sample LTO8 shows an obvious particle agglomeration, several small particles stick together to form a large one, showing a poor dispersity.

To investigate the influence of heat-treatment temperature on the electrochemical performance, the cycling performances of the samples LTO4, LTO6 and LTO8 were examined. As shown in Fig. 8, sample LTO4 displays extremely high irreversible capacity compared to other samples, mainly resulting from the remained organic groups on the particle surface due to its lower heating temperature. All samples show good cycling stability since the second cycle, while sample LTO6 exhibits the highest electrochemical capacity of $150 \mathrm{mAh} / \mathrm{g}$ among all the samples. To understand the dependence of electrochemical capacity of LTO on the heating temperature, several
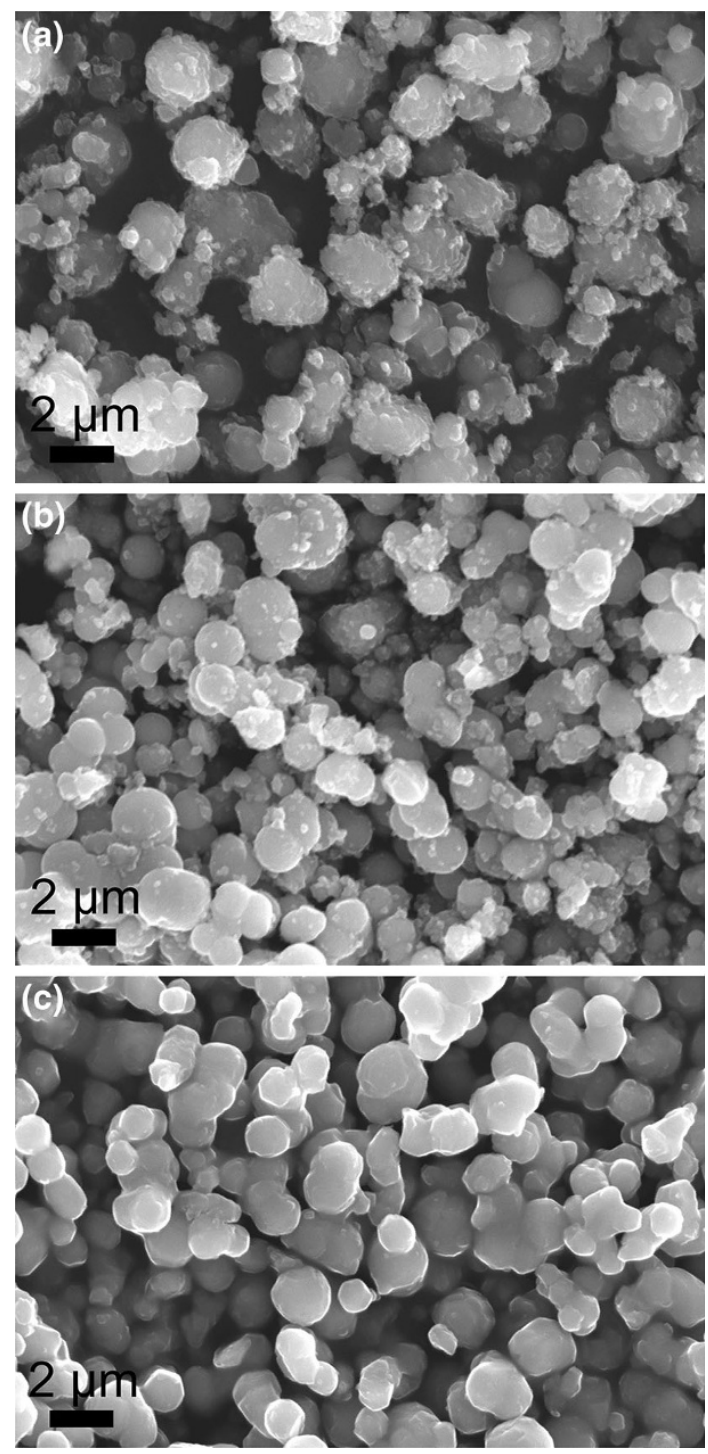

Fig. 7 SEM images of samples a LTO4, b LTO6, c LTO8

aspects should be taken into account. The first is the crystallinity of powders. High crystallinity is usually beneficial to the good electrochemical performance of $\mathrm{Li}_{4} \mathrm{Ti}_{5} \mathrm{O}_{12}$ negative electrode [9]. On the other hand, particle agglomeration is unfavorable for the diffusion of lithium ions due to the elongated diffusion distance. The characteristics of good crystallinity and small particle size of sample LTO6 guarantee its high specific capacity. Due to the obvious particle agglomeration, sample LTO8 exhibits the lowest specific capacity, even worse than sample LTO4. Besides the long diffusion path of lithium ions of the agglomerated particles that impedes the kinetics of lithium intercalation into the LTO8 host structure, the lowered specific surface area should be taken into consideration because it can reduce the contact area between the electrode and the $\mathrm{AB}$, and therefore deteriorate the electronic conduction. Furthermore, the lowered specific 


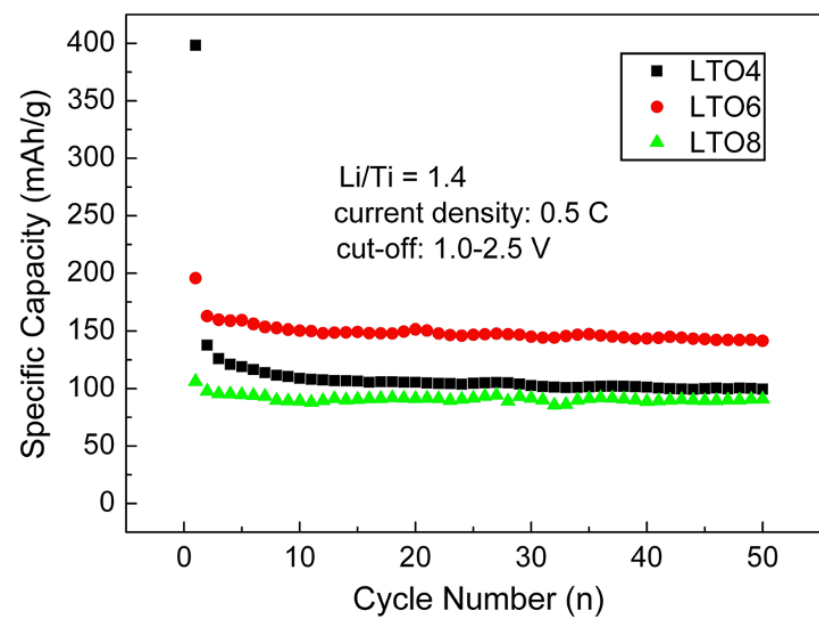

Fig. 8 Discharge capacities of samples LTO4, LTO6 and LTO8

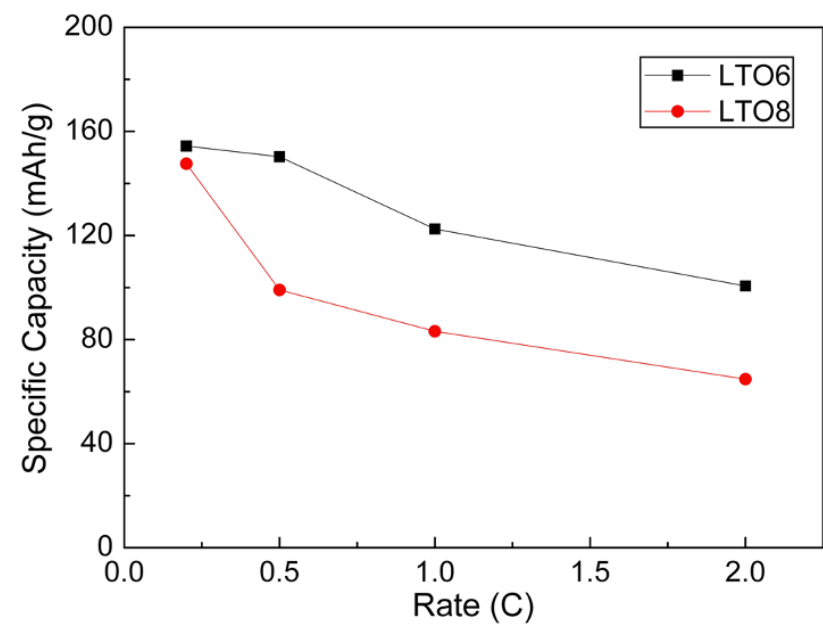

Fig. 9 Specific capacities of samples LTO6 and LTO8 at different rates between 1.0 and $2.5 \mathrm{~V}$

surface area can result in the increase in actual current density on particle surface, and thus cause a large polarization of the electrode, which is another reason for the low specific capacity of sample LTO8 [6, 31-33].

Figure 9 illustrates the rate capabilities of LTO6 and LTO8 electrodes. The discharge capacity of both samples decreases gradually with increasing current density. Nevertheless, the sample LTO6 maintains a higher reversible capacity at the same current density as compared to the sample LTO8, indicating the good rate capability of sample LTO6. At lower current density of $0.2 \mathrm{C}$, both the samples reveal relatively good capacity characteristics due to the sufficient insertion/extraction of lithium ions. High current density makes their specific capacity different. The capacity ratio of $C_{2} \mathrm{C} / C_{0.2 \mathrm{C}}$ is 0.65 and 0.44 for samples LTO6 and LTO8, respectively. The good rate capability as well as the high specific capacity of sample LTO6 makes it a promising material for a better commercial application.

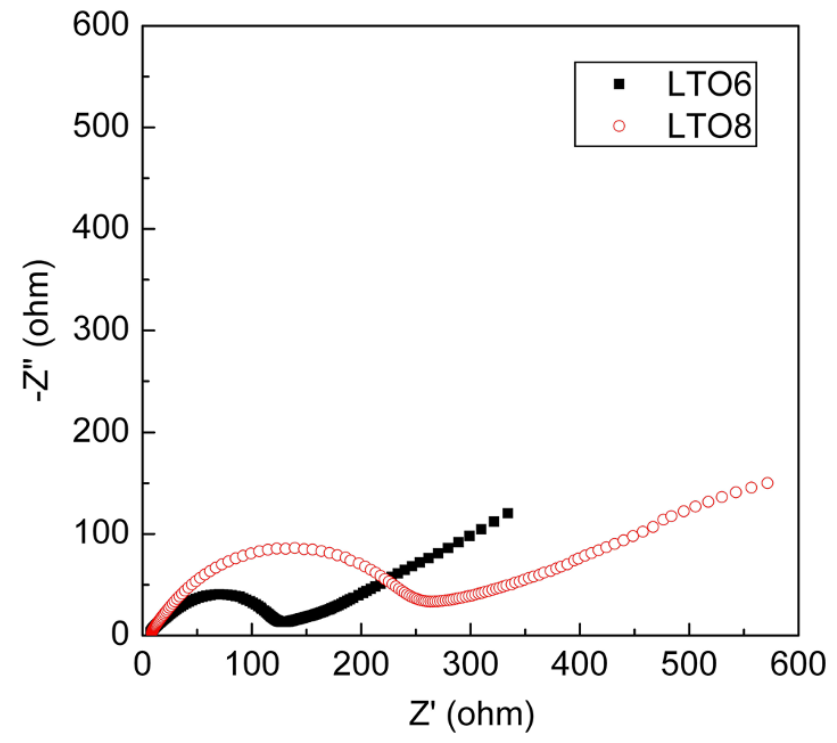

Fig. 10 AC impedance spectra of $\mathrm{Li} / \mathrm{Li}_{4} \mathrm{Ti}_{5} \mathrm{O}_{12}$ cells with LTO6 and LTO8 as active material

AC impedance measurement was performed on LTO6 and LTO8 electrodes, the results are shown in Fig. 10. Each curve is comprised of a depressed semi-circle in the high-medium frequency region and an oblique straight line in the low frequency region. The semi-circle in the highmedium frequency region is mainly related to the chargetransfer process, while the inclined line in the low frequency region is attributed to the Warburg impedance that reflects lithium-ion diffusion behavior in the $\mathrm{Li}_{4} \mathrm{Ti}_{5} \mathrm{O}_{12}$ electrode [34]. Sample LTO6 displays a significantly lower resistance of charge transfer than that of sample LTO8, which is certainly associated with the larger specific surface area of active material LTO6. These results can interpret well the experimental results in Figs. 8 and 9.

\section{Conclusion}

Pure and well-crystallized $\mathrm{Li}_{4} \mathrm{Ti}_{5} \mathrm{O}_{12}$ powders were synthesized from $\operatorname{Ti}\left(\mathrm{O}\left(\mathrm{CH}_{2}\right)_{3} \mathrm{CH}_{3}\right)_{4}$ and $\mathrm{LiAc}$ by solvothermal route involving a further heat treatment at relatively low temperature with short dwelling time. The Li/Ti molar ratio in starting materials and post-heat-treatment temperature have strong impacts on the electrochemical performance of $\mathrm{Li}_{4} \mathrm{Ti}_{5} \mathrm{O}_{12}$ anode material. Excess lithium, compared to the theoretical value in $\mathrm{Li}_{4} \mathrm{Ti}_{5} \mathrm{O}_{12}$, is required for the synthesis of pure-phase $\mathrm{Li}_{4} \mathrm{Ti}_{5} \mathrm{O}_{12}$ in this preparation condition. Low $\mathrm{Li} / \mathrm{Ti}$ ratio $(<1.4 \mathrm{in}$ atom) easily results in the coexistence of the secondary phase $\mathrm{TiO}_{2}$, while high treatment temperature leads to particle agglomeration of $\mathrm{Li}_{4} \mathrm{Ti}_{5} \mathrm{O}_{12}$ powders. The former causes the decrease in specific capacity, but the latter deteriorates the rate capability of 
electrode. The $600{ }^{\circ} \mathrm{C}$-treated sample LTO6 with starting $\mathrm{LiAc} / \mathrm{Ti}(\mathrm{OR})_{4}=1.4$ exhibits the highest specific capacity and best rate performance due to its high purity, good crystallinity and excellent dispersity. At 0.5 C, LTO6 displays a stable reversible capacity of ca. $150 \mathrm{mAh} / \mathrm{g}$. EIS measurement reveals that LTO6 has lower charge-transfer resistance compared to the $800{ }^{\circ} \mathrm{C}$-treated LTO8, which is mainly attributable to the high specific surface area and small particle size of sample LTO6.

Acknowledgments This work was financially supported by National Basic Research Program of China (2013CB934003), "863" program (2013AA050902), National Nature Science Foundation of China (21273019) and the Foundamental Research Funds for the Central Universities (FRF-MP-13-002B).

Open Access This article is distributed under the terms of the Creative Commons Attribution License which permits any use, distribution, and reproduction in any medium, provided the original author(s) and the source are credited.

\section{References}

1. Tarascon, J.-M., Armand, M.: Issues and challenges facing rechargeable lithium batteries. Nature 414, 359-367 (2001)

2. Sato, K., Noguchi, M., Demachi, A., Oki, N., Endo, M.: A mechanism of lithium storage in disordered carbons. Science $\mathbf{2 6 4}$, 556-558 (1994)

3. Scrosati, B., Garche, J.: Lithium batteries: status, prospects and future. J. Power Sources 195, 2419-2430 (2010)

4. Ohzuku, T., Ueda, A., Yamamoto, N.: Zero-strain insertion material of $\mathrm{Li}\left[\mathrm{Li}_{1 / 3} \mathrm{Ti}_{5 / 3}\right] \mathrm{O}_{4}$ for rechargeable lithium cells. J. Electrochem. Soc. 142, 1431-1435 (1995)

5. Ariyoshi, K., Yamato, R., Ohzuku, T.: Zero-strain insertion mechanism of $\mathrm{Li}\left[\mathrm{Li}_{1 / 3} \mathrm{Ti}_{5 / 3}\right] \mathrm{O}_{4}$ for advanced lithium-ion (shuttlecock) batteries. Electrochim. Acta 51, 1125-1129 (2005)

6. Jiang, C., Ichihara, M., Honma, I., Zhou, H.: Effect of particle dispersion on high rate performance of nano-sized $\mathrm{Li}_{4} \mathrm{Ti}_{5} \mathrm{O}_{12}$ anode. Electrochim. Acta 52, 6470-6475 (2007)

7. Yuan, T., Cai, R., Shao, Z.: Different effect of the atmospheres on the phase formation and performance of $\mathrm{Li}_{4} \mathrm{Ti}_{5} \mathrm{O}_{12}$ prepared from ball-milling-assisted solid-phase reaction with pristine and carbon-precoated $\mathrm{TiO}_{2}$ as starting materials. J. Phys. Chem. C 115, 4943-4952 (2011)

8. Patoux, S., Daniel, L., Bourbon, C., Lignier, H., Pagano, C., Cras, F.L., Jouanneau, S., Martinet, S.: High voltage spinel oxides for Li-ion batteries: from the material research to the application. J. Power Sources 189, 344-352 (2009)

9. Guerfi, A., Sévigny, S., Lagacé, M., Hovington, P., Kinoshita, K., Zaghib, K.: Nano-particle $\mathrm{Li}_{4} \mathrm{Ti}_{5} \mathrm{O}_{12}$ spinel as electrode for electrochemical generators. J. Power Sources 119-121, 88-94 (2003)

10. Prakash, A.S., Manikandan, P., Ramesha, K., Sathiya, M., Tarascon, J.-M., Shukla, A.K.: Solution-combustion synthesized nanocrystalline $\mathrm{Li}_{4} \mathrm{Ti}_{5} \mathrm{O}_{12}$ as high-rate performance Li-ion battery anode. Chem. Mater. 22, 2857-2863 (2010)

11. Yin, S.Y., Song, L., Wang, X.Y., Zhang, M.F., Zhang, K.L., Zhang, Y.X.: Synthesis of spinel $\mathrm{Li}_{4} \mathrm{Ti}_{5} \mathrm{O}_{12}$ anode material by a modified rheological phase reaction. Electrochim. Acta 54, 5629-5633 (2009)
12. Huang, S., Wen, Z., Zhu, X., Lin, Z.: Effects of dopant on the electrochemical performance of $\mathrm{Li}_{4} \mathrm{Ti}_{5} \mathrm{O}_{12}$ as electrode material for lithium ion batteries. J. Power Sources 165, 408-412 (2007)

13. Chen, C.H., Vaughey, J.T., Jansen, A.N., Dees, D.W., Kahaian, A.J., Goacher, T., Thackeray, M.M.: Studies of Mg-substituted $\mathrm{Li}_{4}-{ }_{\mathrm{x}} \mathrm{Mg}_{\mathrm{x}} \mathrm{Ti}_{5} \mathrm{O}_{12}$ spinel electrodes $(0 \leq \mathrm{x} \leq 1)$ for lithium batteries. J. Electrochem. Soc. 148, A102-A104 (2001)

14. Wolfenstine, J., Allen, J.L.: Electrical conductivity and charge compensation in Ta doped $\mathrm{Li}_{4} \mathrm{Ti}_{5} \mathrm{O}_{12}$. J. Power Sources 180, 582-585 (2008)

15. Cheng, L., Yan, J., Zhu, G.N., Luo, J.Y., Wang, C.X., Xia, Y.Y.: General synthesis of carbon-coated nanostructure $\mathrm{Li}_{4} \mathrm{Ti}_{5} \mathrm{O}_{12}$ as a high rate electrode material for $\mathrm{Li}$-ion intercalation. J. Mater. Chem. 20, 595-602 (2010)

16. Huang, S., Wen, Z., Zhang, J., Yang, X.: Improving the electrochemical performance of $\mathrm{Li}_{4} \mathrm{Ti}_{5} \mathrm{O}_{12} / \mathrm{Ag}$ composite by an electroless deposition method. Electrochim. Acta 52, 3704-3708 (2007)

17. Sorensen, E.M., Barry, S.J., Jung, H.-K., Rondinelli, J.R., Vaughey, J.T., Poeppelmeier, K.R.: Three-dimensionally ordered macroporous $\mathrm{Li}_{4} \mathrm{Ti}_{5} \mathrm{O}_{12}$ : effect of wall structure on electrochemical properties. Chem. Mater. 18, 482-489 (2006)

18. Bach, S., Pereira-Ramos, J.P., Baffier, N.: Electrochemical properties of sol-gel $\mathrm{Li}_{4 / 3} \mathrm{Ti}_{5 / 3} \mathrm{O}_{4}$. J. Power Sources 81-82, 273-276 (1999)

19. Fattakhova, D., Petrykin, V., Brus, J., Kostlánová, T., Dědeček, J., Krtil, P.: Solvothermal synthesis and electrochemical behavior of nanocrystalline cubic $\mathrm{Li}-\mathrm{Ti}-\mathrm{O}$ oxides with cationic disorder. Solid State Ion. 176, 1877-1885 (2005)

20. Kostlánová, T., Dědeček, J., Krtil, P.: The effect of the inner particle structure on the electronic structure of the nano-crystalline Li-Ti-O spinels. Electrochim. Acta 52, 1847-1856 (2007)

21. Li, J., Tang, Z., Zhang, Z.: Controllable formation and electrochemical properties of one-dimensional nanostructured spinel $\mathrm{Li}_{4} \mathrm{Ti}_{5} \mathrm{O}_{12}$. Electrochem. Commun. 7, 894-899 (2005)

22. Lee, S.C., Lee, S.M., Lee, J.W., Lee, J.B., Lee, S.M., Han, S.S., Lee, H.C., Kim, H.J.: Spinel $\mathrm{Li}_{4} \mathrm{Ti}_{5} \mathrm{O}_{12}$ nanotubes for energy storage materials. J. Phys. Chem. C 113, 18420-18423 (2009)

23. Yuan, T., Wang, K., Cai, R., Ran, R., Shao, Z.: Cellulose-assisted combustion synthesis of $\mathrm{Li}_{4} \mathrm{Ti}_{5} \mathrm{O}_{12}$ adopting anatase $\mathrm{TiO}_{2}$ solid as raw material with high electrochemical performance. J. Alloys Compd. 477, 665-672 (2009)

24. Zhang, B., Liu, Y., Huang, Z., Oh, S., Yu, Y., Mai, Y.-W., Kim, J.-K.: Urchin-like $\mathrm{Li}_{4} \mathrm{Ti}_{5} \mathrm{O}_{12}$-carbon nanofiber composites for high rate performance anodes in Li-ion batteries. J. Mater. Chem. 22, 12133-12140 (2012)

25. Huang, S., Wen, Z., Gu, Z., Zhu, X.: Preparation and cycling performance of $\mathrm{Al}^{3+}$ and $\mathrm{F}^{-}$co-substituted compounds $\mathrm{Li}_{4} \mathrm{Al}_{\mathrm{x}}$ $\mathrm{Ti}_{5}-{ }_{\mathrm{x}} \mathrm{F}_{\mathrm{y}} \mathrm{O}_{12}-\mathrm{y}$. Electrochim. Acta 50, 4057-4062 (2005)

26. Koudriachova, M.V., Harrison, N.M., de Leeuw, S.W.: First principles predictions for intercalation behavior. Solid State Ion. 175, 829-834 (2004)

27. Zachau-Christiansen, B., West, K., Jacobsen, T., Atlung, S.: Lithium insertion in different $\mathrm{TiO}_{2}$ modifications. Solid State Ion. 28-30, 1176-1182 (1988)

28. Liu, J., Li, X., Yang, J., Geng, D., Li, Y., Wang, D., Li, R., Sun, X., Cai, M., Verbruggeb, M.W.: Microwave-assisted hydrothermal synthesis of nanostructured spinel $\mathrm{Li}_{4} \mathrm{Ti}_{5} \mathrm{O}_{12}$ as anode materials for lithium ion batteries. Electrochim. Acta 63, 100-104 (2012)

29. Chen, J.S., Lou, X.W.: The superior lithium storage capabilities of ultra-fine rutile $\mathrm{TiO}_{2}$ nanoparticles. J. Power Sources 195, 2905-2908 (2010)

30. Colin, J.F., Godbole, V., Novák, P.: In situ neutron diffraction study of $\mathrm{Li}$ insertion in $\mathrm{Li}_{4} \mathrm{Ti}_{5} \mathrm{O}_{12}$. Electrochem. Commun. 12, 804-807 (2010) 
31. Jung, H.G., Kim, J., Scrosati, B., Sun, Y.K.: Micron-sized, carbon-coated $\mathrm{Li}_{4} \mathrm{Ti}_{5} \mathrm{O}_{12}$ as high power anode material for advanced lithium batteries. J. Power Sources 196, 7763-7766 (2011)

32. Zhang, N., Liu, Z., Yang, T., Liao, C., Wang, Z., Sun, K.: Facile preparation of nanocrystalline $\mathrm{Li}_{4} \mathrm{Ti}_{5} \mathrm{O}_{12}$ and its high electrochemical performance as anode material for lithium-ion batteries. Electrochem. Commun. 13, 654-656 (2011)

33. Aricò, A.S., Bruce, P., Scrosati, B., Tarascon, J.-M., van Schalkwijk, W.: Nanostructured materials for advanced energy conversion and storage devices. Nat. Mater. 4, 366-377 (2005)
34. Yoshikawa, D., Kadoma, Y., Kim, J.-M., Ui, K., Kumagai, N., Kitamura, N., Idemoto, Y.: Spray-drying synthesized lithiumexcess $\mathrm{Li}_{4}+{ }_{\mathrm{x}} \mathrm{Ti}_{5}-{ }_{\mathrm{x}} \mathrm{O}_{12}-\delta$ and its electrochemical property as negative electrode material for Li-ion batteries. Electrochim. Acta 55, 1872-1879 (2010) 